\title{
下方加熱を受ける多孔質体内での自然対流
}

\author{
木村 繁男* \\ Natural Convection in a Saturated Porous Medium \\ Heated from below
}

\author{
Shigeo Kimura
}

\begin{abstract}
Convection in a fluid-saturated porous layer at high Rayleigh numbers is briefly reviewed. When a saturated porous layer is subjected to bottom heating, steady convection sets in with the increase of the Rayleigh number $R$ beyond the critical value. If the porous layer has an infinite horizontal extent, the critical value is $R=4 \pi^{2}=40$. Further increase of the Rayleigh number transforms steady convection to a time-dependent or oscillatory state. In a two-dimensional square the transition from steady to oscillatory state takes place at $\mathrm{R}=390$. The first oscillatory convection characterized by the oscillation of average heat flux (Nusselt number) exhibits a simply periodic state. The frequency at the onset of the oscillation is about 83 in a diffustion time. The oscillation frequency in general increases with the Rayleigh number. The flow and temperature fields possess center-symmetric patterns. At the Rayleigh number somewhere between 800 and 1000 the convective state becomes chaotic with a broad band noise in a spectral power diagram of the Nusselt number oscillation. The flow and temperature patterns at the chaotic state no longer possess the center-symmetry. The physical mechanism responsible for the oscillation is identified as a thermal boundary layer instability.

It has been also established that oscillatory condition exists in a three-dimensional space. The onset of oscillation takes place at $\mathrm{R}=575$. The first oscillatory state is simply periodic with the frequency 170. At $R=650$ the convection becomes a more complex state with at least two fundamental frequencies.
\end{abstract}

Key words: natural convection, porous medium, heat transfer, oscillatory convection, chaotic convection

1.はじめに

飽和多孔質体内での流動は地下水流れのモデルと

*工業技術院 東北工業技術試験所
して広く用いられている。従って飽和多孔質体内の 温度勾配に基づく自然対流（流体の密度差がドライ ブする流動）の存在と、それに伴う熱・物質の移動 機構について理解することは地下帯水層による蓄熱 及びその利用を考える上で極めて重要である。一般 
に自然対流の存在は熱移動を活発化し、蓄熱という 目的に対しては不利益をもたらす。従ってどのよう な条件のもとで対流が発生するのか、またそれはど の位の強度なのかを予測することが地下帯水層を用 いた蓄熱技術の実用化を行う上で不可欠となる。飽 和多孔質体内での対流について考える場合、境界条 件の与え方により 2 つに大別して扱うのが便利であ る。一つは水平方向に温度差が与えられる場合で、 この様な条件が与えられると温度勾配が小さくても 対流は常に発生する。もう一つは温度勾配が鉛直方 向に与えられる場合で、この時は温度勾配がある臨 界值を超えない限り対流は発生しない。今回は後者 の場合に限って 2 次元及び 3 次元の閉空間内での自 然対流の発生と対流による熱移動及び流動パターン について述べる。対流発生の条件は温度勾配のみで なく、それを一つの因子に含む無次元数レーレー数 Rにより決定される。

飽和多孔質体が下方加熱を受ける場合の研究は古 くから行われており、対流発生については Lapwood (1948)、2 次元定常対流についてはElder （1967）の先駆的研究が知られている。またこの基 礎的問題の地熱貯留層解析への応用については、 Cheng（1978）のレヴューペーパーがある。下方加 熱によるニュートン流体の活発な対流領域、すなわ ち高レーレー数においては対流が時間依存性を有す るようになることが知られている。 Horne \& 0'sullivan（1974）及びCaltagirone（1975）は、時 間依存性を有する対流が飽和多孔質体内での対流で も存在することを初めて明らかにした。2 次元の単 一七ル対流の場合、定常な対流から時間依存性を有 する振動流れに遷移するレーレー数は390であるこ とが、その時の振動流れは単振動を有し、振動数は 熱拡散率に基づく無次元時間で83であること等が Kimura et al. (1987) 及びAidun \& Steen (1987) により示された。さらにKimura et al. (1986, 1989) は、さらに高レーレー数域での 2 次元、3 次元対流 がどのような構造を有するのかを数值的に明らかに した。また最近ではRiley \& Winters（1990）が傾 斜した正方形断面内の対流パターンの選択について 検討を加えている。

そこで本論文では、はじめに解析を行う上での 諸々の仮定について述べ、流動及び熱移動の支配方 程式を導く。次に線形解析により対流の発生パター ンについて述べる。さらに数值計算による高レー
レー数領域での対流の様子を示す。特に定常な対流 が時間依存性を有する振動流に遷移する過程につい て紹介する。

\section{2. 基礎方程式}

まず流体で飽和した高さ $\mathrm{d}$ の直す体を考える。直 方体の全ての壁面は不透水性であると仮定する。下 面壁温度は上面壁温度 $\mathrm{T}_{0}$ より $\Delta \mathrm{T}$ だけ高温に保た れており、側壁に対しては断熱条件が満たされてい るとする。流動に対してはダルシー則が成立し、流 体は非圧縮性であり、その物性值は一定とする。た だし、温度変化に伴う諸物理量の変化のうち浮力の 項に関係する密度変化以外を無視するというブシネ スク近似が成立するものとする。この時、鉛直方向 上向きに $\mathrm{z}$ 軸を取ると、質量保存則、運動量保存則、 エネルギー保存則は以下の様に書ける（Straus and Schubert, 1979)。

$$
\begin{aligned}
& \nabla \cdot \mathbf{u}=0, \\
& \nabla \mathrm{p}+\rho \alpha\left(T-T_{0}-\Delta T+\Delta T z / \mathrm{d}\right) \mathrm{g}+ \\
& \quad(\mu / \mathrm{K}) \mathbf{u}=0,
\end{aligned}
$$

$$
\chi \partial T / \partial \mathrm{t}+\rho \mathrm{cu} \cdot \nabla \mathrm{T}=\mathrm{k} \nabla^{2} \mathrm{~T},
$$

ここで、u、p、 $\rho 、 \alpha 、 g 、 \mu 、 \mathrm{~K} 、 \chi 、 \mathrm{c}, \mathrm{k}$ は、 それぞれダルシー速度ベクトル、圧力、流体密度、 体積膨張率、重力加速度べクトル、流体の粘性、多 孔質体の透水率、飽和多孔質体の熱容量、流体の比 熱、飽和多孔質体の熱伝導率である。また（2）式 中の浮力を表す項で $\mathrm{T}_{0}+\Delta \mathrm{T}-\Delta \mathrm{Tz} / \mathrm{d}$ は熱伝 導型の温度分布を示す。さらに以下の無次元化をほ どこす。

$$
\begin{gathered}
\xi=\frac{\mathrm{x}}{\mathrm{d}}, \quad \eta=\frac{\mathrm{y}}{\mathrm{d}}, \quad \zeta=\frac{\mathrm{z}}{\mathrm{d}}, \bar{\nabla}=\mathrm{d} \nabla, \\
\mathrm{r}=\frac{\mathrm{kt}}{\chi \mathrm{d}^{2}}, \overline{\mathrm{u}}=\frac{\rho \mathrm{cd}}{\mathrm{k}} \mathrm{u}, \overline{\mathrm{v}}=\frac{\rho \mathrm{cd}}{\mathrm{k}} \mathrm{v}, \\
\overline{\mathrm{w}}=\frac{\rho \mathrm{cd}}{\mathrm{k}} \mathrm{w}, \overline{\mathrm{u}}=\frac{\rho \mathrm{cd}}{\mathrm{k}} \mathrm{u}, \\
\theta=\frac{T-T_{0}-\Delta T+\Delta T \mathrm{z} / \mathrm{d}}{\Delta T}, \quad \pi=\frac{K \rho \mathrm{c}}{\mu \mathrm{k}} \mathrm{p},
\end{gathered}
$$


ここで $\mathrm{u} 、 \mathrm{v} 、 \mathrm{w}$ は $\mathrm{x} 、 \mathrm{y} 、 \mathrm{z}$ 方向のダルシー速度で ある。また各壁面に沿うせん断応力はゼ口、すなわ ち滑面を仮定した。これらの無次元量を代入すると、 式（1）-（3）と対応する境界条件は次のように なる。

$$
\begin{aligned}
& \bar{\nabla} \cdot \overline{\mathrm{u}}=0, \\
& \bar{\nabla} \pi+\overline{\mathrm{u}}-\mathrm{R} \theta \hat{\zeta}=0, \\
& \partial \theta / \partial \mathrm{r}+\overline{\mathrm{u}} \cdot \bar{\nabla} \theta=\overline{\mathrm{w}}+\bar{\nabla}^{2} \theta, \\
& \theta=\overline{\mathrm{w}}=0 \quad \text { on } \quad \xi=0,1, \\
& \partial \theta / \partial \xi=\overline{\mathrm{u}}=0 \quad \text { on } \quad \xi=0, \mathrm{l} / \mathrm{d}, \\
& \partial \theta / \partial \eta=\overline{\mathrm{v}}=0 \quad \text { on } \quad \eta=0, \mathrm{~b} / \mathrm{d} .
\end{aligned}
$$

ここで $1 、 b 、 \xi 、 R 、 は 、$ 直方体の水平方向の各 辺の長さ、 $z$ 方向の単位ベクトル、レーレー数であ る。この場合レーレー数は次式で定義される無次元 数である。

$$
\mathrm{R}=\alpha \rho_{\rho}^{2} K \operatorname{cd} \Delta T / \mu \mathrm{k}
$$

図 1 に物理モデルと夾標系を示す。また、次のよう なポテンシャル $\phi$ を導入することにより、質量保存 則（連続の式）は自動的に満足される。

$$
\overline{\mathrm{u}}=\phi_{\xi \xi}, \quad \overline{\mathrm{v}}=\phi_{\xi \eta}, \quad \overline{\mathrm{w}}=-\phi_{\xi \xi}-\phi_{\eta \eta}
$$

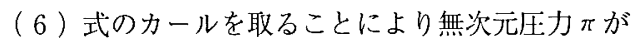
消去される。これに（10）式を代入した運動量保存 の式とエネルギー保存の式から無次元温度 $\theta$ を消去 すると申についての単一支配方程式を得る。

$$
\begin{gathered}
\partial \nabla^{2} \phi / \partial \mathrm{r}+\phi_{\xi \zeta} \bar{\nabla}^{2} \phi_{\xi}+\phi_{\eta \zeta} \bar{\nabla}^{2} \phi_{\eta}-\left(\phi_{\xi \xi}+\phi_{\eta \eta}\right) \\
\bar{\nabla}^{2} \phi_{\zeta}=\bar{\nabla}^{4} \phi+R\left(\phi_{\xi \xi}+\phi_{\eta \eta}\right)
\end{gathered}
$$

申の境界条件は次のように書ける。

$$
\begin{array}{ll}
\phi_{\xi \xi}+\phi_{\eta \eta}=\phi_{\zeta \zeta}=0 \quad \text { on } \quad \zeta=0,1, \\
\phi_{\xi \zeta}=\bar{\nabla}^{2} \phi_{\xi}=0 \quad \text { on } \quad \xi=0,1 / \mathrm{d}, \\
\phi_{\eta \zeta}=\bar{\nabla}^{2} \phi_{\eta}=0 \quad \text { on } & \mathrm{g}=0, \mathrm{~b} / \mathrm{d} .
\end{array}
$$

申を以下のようにフーリ工級数に展開すると上記の 境界条件はすべて自動的に満足される。

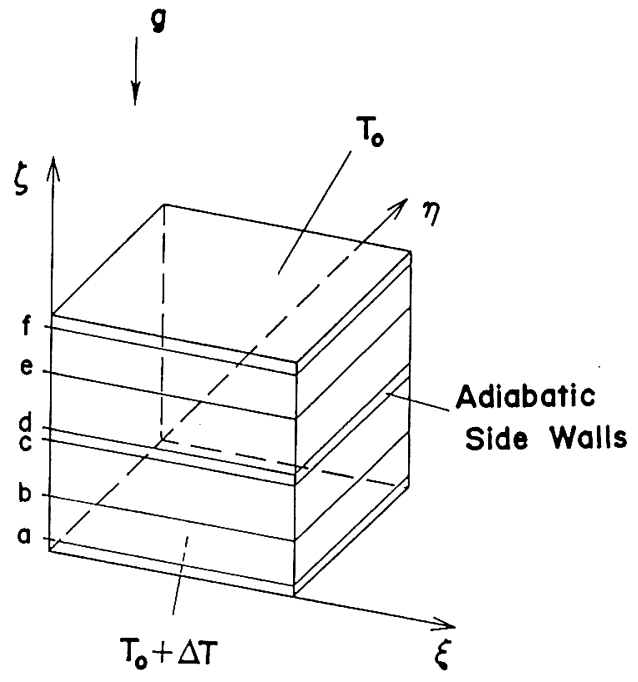

図-1 物理モデルと座標系（Kimura et al. (1989) に依 る)

Fig. 1 Schmatic diagram of saturated porous cube heated from below and the coordinate system (After Kimura et al., 1989)

$$
\begin{aligned}
\phi & =\sum_{\mathrm{n}=1}^{\infty} \sum_{j=0}^{\infty} \sum_{\mathrm{m}=0}^{\infty} \phi_{n j m}(\tau) \sin n \pi \zeta \cos \frac{j \pi \xi}{1 / \mathrm{d}} \\
& \cos \frac{m \pi \eta}{\mathrm{b} / \mathrm{d}}
\end{aligned}
$$

これをфについて単一支配方程式に代入し、関数の 直交性を利用するとフーリ工係数 $\phi_{\mathrm{njm}}(\tau)$ につ いての連立非線形常微分方程式を得る(ガラーキン 法)。この連立非線形常方程式は数值的に解かれる。 非線形問題に対して上記のようなガラーキン法を 用いると級数同士の積を計算しなければならずフー リ工級数の項数が多くなると膨大な時間を要するこ とになる。この級数同士の積の計算をさける目的で、 これらの項を一度周波数空間から物理空間にもどし て非線形項の計算を物理空間で行った（Gottlieb \& Orszag, 1977)。周波数空間から物理空間への移動 (変換) 及び逆の移動（逆変換）は高速フーリエ変 換（FFT）を用いて行った。本報で紹介する多孔質 内対流の計算では通常のガラーキン法に比べ 2 次元 計算で数十倍、3 次元計算で約百倍程度の高速化が それぞれ達せられた。

下面壁から上面壁への熱伝達は一般的にヌッセル 
ト数と呼ばれる無次元数により表すのが習わしと なっている。ヌッセルト数は熱伝導のみの場合に比 へ、対流の存在によりどの程度熱が余分に運ばれて いるかを示している。

$$
\overline{\mathrm{Nu}} \equiv \frac{\mathrm{q}}{\mathrm{k} \Delta T / \mathrm{d}}=1-\sum_{\mathrm{n}=1}^{\infty} \frac{\mathrm{n}^{3} \pi^{3}}{\mathrm{R}} \phi_{\mathrm{n} 00}(\tau)
$$

ここで $\mathrm{q}$ は単位面積当たりの平均熱伝達量である。 フーリ工級数は $\mathrm{n}+\mathrm{j}+\mathrm{m} \leqq \mathrm{N}$ と成るような正の整 数 $\mathrm{N}$ を用いて打ち切った。 3 次元計算では $\mathrm{N}=26$ 、 30、34を、また 2 次元計算では $\mathrm{n}+\mathrm{j} \leqq N$ で $\mathrm{N}=18$ から42を用いて計算を行った (Kimura et al., 1986 ; Kimura et al., 1989)。

\section{3. 対流パターン}

本論文では簡単のため立方体及び 2 次元正方形の

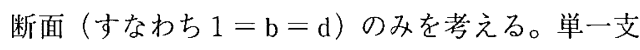
配方程式 (11) 式において、臨界レーレー数近傍を 仮定すると申は小さいため非線形項は線形項に比べ 無視できる。従って線形方程式の中で正の固有值を 持つものがあれば、対応する対流パターンが発生す る可能性がある。この条件から対流のパターンと郜 界レーレー数との関係が導かれる(Lapwood, 1948)。

$$
R_{c r}=\pi^{2}\left(n^{2}+j^{2}+m^{2}\right)^{2} /\left(j^{2}+m^{2}\right)
$$

$\mathrm{n}=1$ で固定し $\mathrm{m}$ を独立变数、 $\mathrm{j}$ をパラメーターと したときの臨界レーレー数の值を図 2 に示す。この 図から最小の臨界レーレー数は $\mathrm{n}=\mathrm{m}=1 、 \mathrm{j}=0$ のときでその值は $4 \pi^{2}$ であることが解る。またこ の時の対流は 2 次元のロール型である。模式的な対 流の様子を図 $3 、 4$ 亿示す。また 3 次元の対流構造 を持つものの中では $\mathrm{n}=\mathrm{j}=\mathrm{m}=1$ の場合が最も レーレー数の值が小さく、その值は $4.5 \pi^{2}$ である。 この場合の対流パターンを図 5 に示す。対流のパ ターンをフーリエ係数のインデックスを用いて呼ぶ と便利である。例えば、2 次元ロール対流は (1，0, 1）モード、上記の 3 次元対流は $(1,1,1)$ モード の様に呼ばれる。一般的にインデックスの值が大き くなると対応する臨界レーレー数も大きくなる。こ れは微小構造を有する対流（例えば、複数のセルを 有する流動パターン) が安定して存在するためには 高いレーレー数が必要であることを意味している。
非線形方程式を数值的に解いた場合でも（1，0，1） モードの場合は $\phi_{101}$ が他の係数に比べて大きく、 $(1,1,1)$ モ一ドの場合は $\phi_{111}$ が支配的である。 レーレー数が十分大きい場合、複数の対流パター ンが安定して存在する可能性が出てくる。すなわち 与えられたレーレー数に対して存在可能なパターン が複数仔在することになる。この時システムが何れ のパターンを選ぶ確率が高いかという問題はたいへ ん興味あるところである。一つの論議として $\overline{\mathrm{Nu}}$ の 大きい方のパターンを選ぶと言うものがある。これ はシステムが安䇥して存在するためには熱力学的な

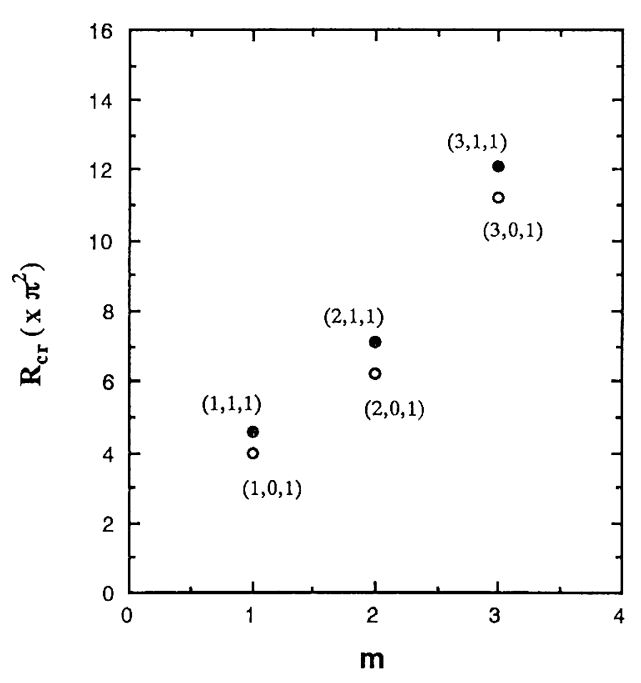

図-2 臨界レーレー数と対流パターン

Fig. 2 Critical Rayleigh numbers and the onset convection modes.

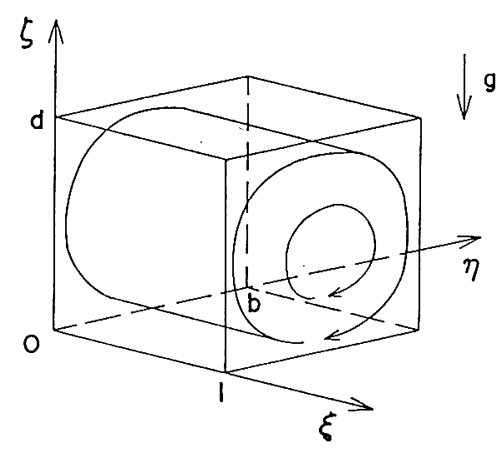

図-3 $\quad(1,0,1)$ モードでの対流パターン

Fig. $3(1,0,1)$ mode convection pattern. 


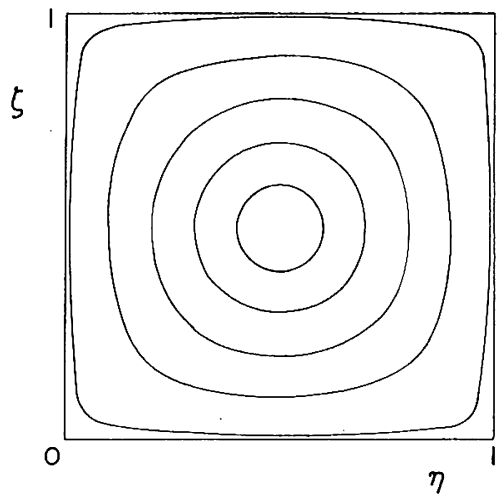

図-4 (1,0,1) モードでの $\zeta-\eta$ 平面上での流線関数 図

Fig. 4 Stream lines of $(1,0,1)$ mode convection.

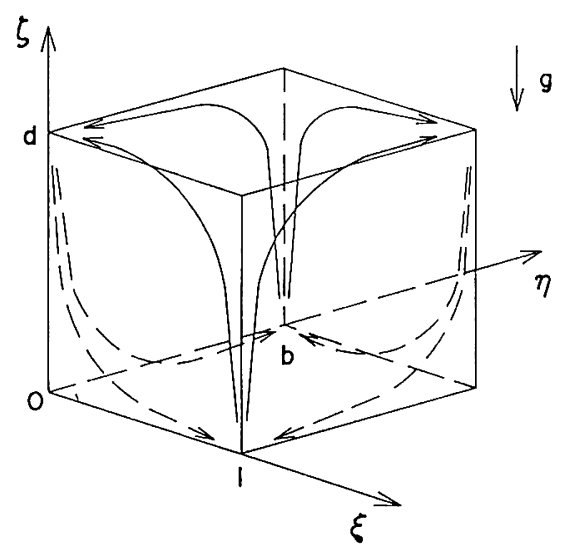

図-5 (1, 1, 1) モードでの対流パターン

Fig. $5(1,1,1)$ mode convection pattern.

物理量が極值を取ることが必要であるという仮説か ら導かれる。しかし著者の経験を述べさせてもらえ ば、これは必ずしも真理ではない。例えば、あるレー レー数に対して 2 つ対流パターンが存在可能な 時、初期值として $\overline{\mathrm{Nu}}$ の小さい方のパターンに対応 するフーリエ係数を大きくするとシステムは $\overline{\mathrm{Nu}} の$ 小さい対流パターンを選択する。すなわち初期值へ の存在度の方が大きい場合が多い (Kimura, 1989)。

\section{2 次元単一セル $((1,0,1)$ モード)}

フーリエ係数 $\phi_{101}$ に大きな值を初期値として与
え（11）式を数值的に解くことにより、高レーレー 数領域での $(1,0,1)$ モードの流動や熱移動につ いて明らかにすることが可能である。 $(1,0,1)$ モー ドは $\mathrm{R}=390$ までは安定な定常解が存在するが、 レーレー数がそれ以上になると振動解に遷移する (Caltagirone, 1975)。振動解の一例 $(\mathrm{R}=500)$ を 図 6 に流線関数と等温線図で示す。下面及び上面に 沿って等温線図に周期的な歪みが発生し、垂直壁に 沿ってそれが開放される様子が見られる。振動流と なる原因が上、下面の温度境界層の不安定に起因し ていることが解る。

図 7 にはさらに高いレーレー数 $(\mathrm{R}=1000)$ で の流動の様子を示す。この場合温度境界層はより一 層薄くなり、プルーム状のコールドスポット（上面） 及びホットスポット（下面）がかなりランダムに形 成されている様子がうかがえる。図 6 において見ら れた流動パターンの対称性も図 7 においてはもはや 存在しない。一般に振動の周期もレーレー数の増加 とともに短くなる。図 8 に時間平均又ッセルト数 $\overline{\mathrm{Nu}}$ をレーレー数 Rの関数として示す。 Rが500以上 ではほぼ $\overline{\mathrm{Nu}} \propto \mathrm{R} の$ 関係が成立している。

\section{3 次元 $(1,1,1)$ モード}

2 次元対流の場合と同様にフーリエ係数 $\phi_{111}$ に 大きな值を与えて数值計算を開始すると $(1,1,1)$ モードの対流パターンが得られる。図 9 に $\mathrm{R}=250$ の場合の各水平断面での $\mathrm{w}$ (鉛直方向の速度成分) の分布を示す。図の $\mathrm{a}-\mathrm{f}$ は水平断面の $\mathrm{z}$ 方向の位置 を示す。下面及び上面の対角線に沿って、それぞれ 上向き及び下向きの流れが形成され、 $z=0.5$ にお いて両者が互いに相手側の流れを分断する形にな る。図10では $\mathrm{R}=450$ の時の $\mathrm{w}$ の分布を示す。 $\mathrm{R}=$ 450 では $\mathrm{R}=250$ に比べ対角線に沿う流れが強く なっている。

(1，1，1）モードは $\mathrm{R}=550$ と575の間で定常流 から振動流れに遷移する。この時の様子を $\overline{\mathrm{Nu}}$ の時 間に対する変動として図11に示す。 $\overline{\mathrm{Nu}}$ は一度大き なオーバーシュート、アンダーシュートをした後一 定值に収束するかのように見えるが、やがて小刻み

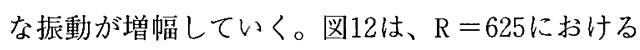

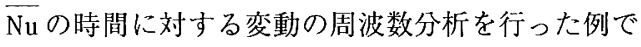
ある。これより $\mathrm{R}=625$ の振動流れが単振動である ことが分かる。 

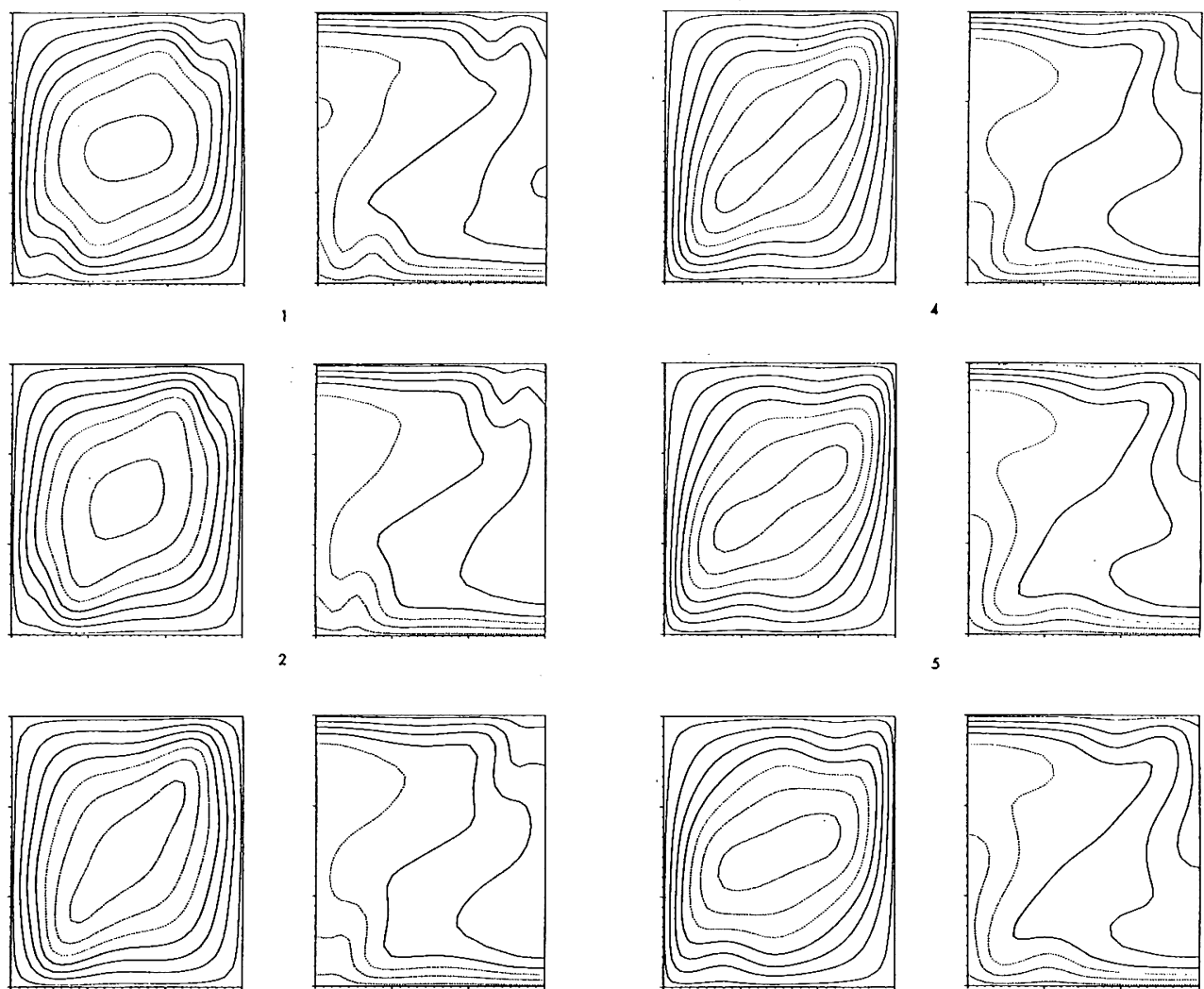

図-6 $R=500$ における流線関数（左側， $\Delta \phi_{\xi}=2.5$ ） と等温線（右側， $\Delta \theta=0.15$ ）。番号 $1 \sim 6$ は $\mathrm{Nu}$ 単一周期内での振動流を 6 分割して示す。番号間の間隔は $\Delta T=0.0015$ (Kimura et al. (1986) に依る)。

Fig. 6 Streamlines (left, $\Delta \phi_{\xi}=2.5$ ) and isotherms (right, $\Delta \theta=0.15$ ) at $R=500$. The nondimensional time interval between successive figures $1-6$ is 0.0015 . The system is simply periodic (After Kimura et al., 1986). 

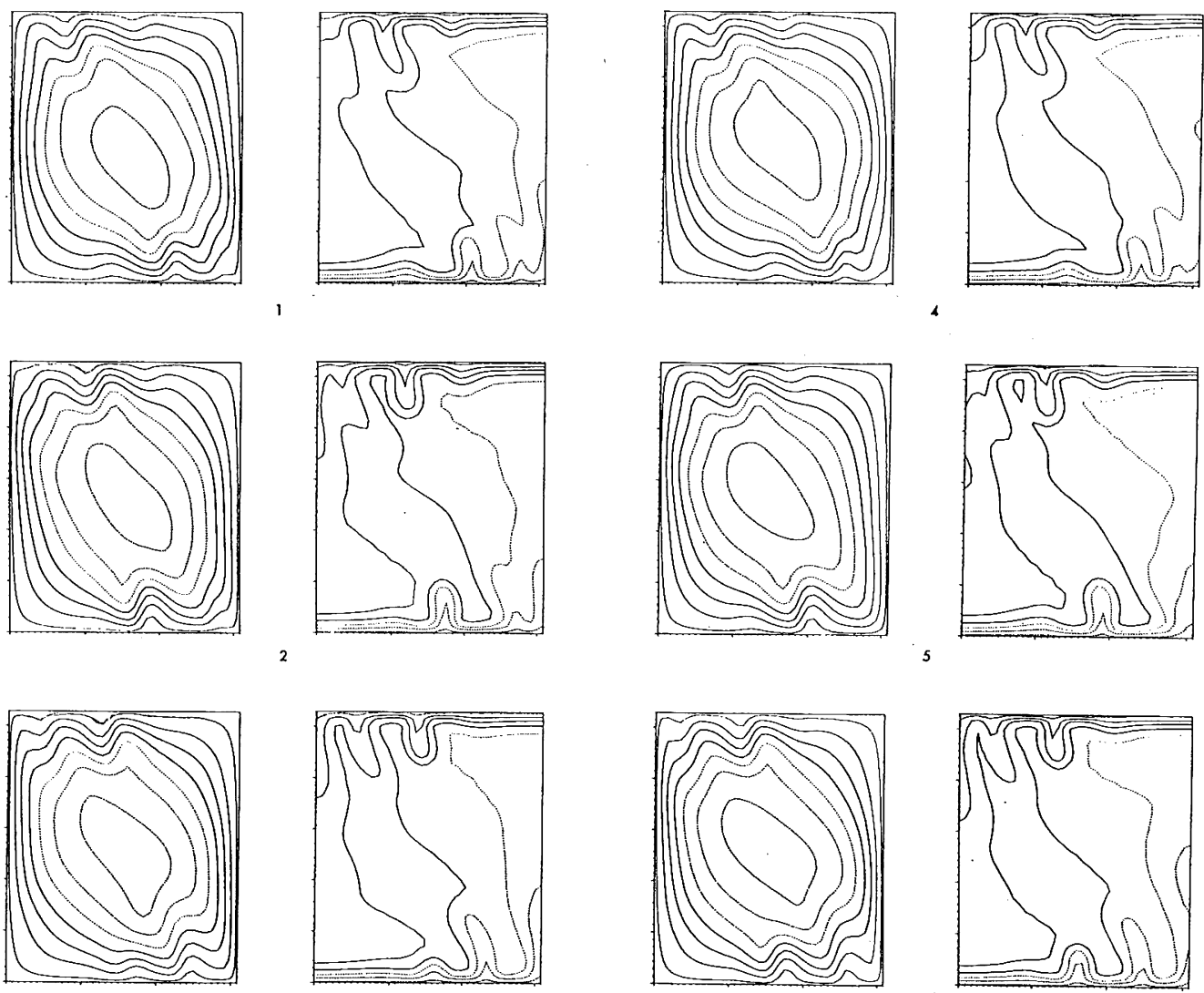

図-7 $R=1000$ におる流線関数（左側， $\Delta \phi_{\xi}=5$ ） と等温線（右側， $\Delta \theta=0.15$ ）。番号 $1 \sim 6$ は $\mathrm{Nu}$ の非周期的振動流の様子を示す。番号間の間隔は $\Delta T=0.0016$ (Kimura et al. (1986) に依 る)。

Fig. 7 Streamline $\left(\Delta \phi_{\xi}=5\right)$ and isothermal $(\Delta \theta=0.15)$ patterns at $R=1000$. The nondimensional time interval between successive figures $1-6$ is 0.0015 (After Kumura et al., 1986). 


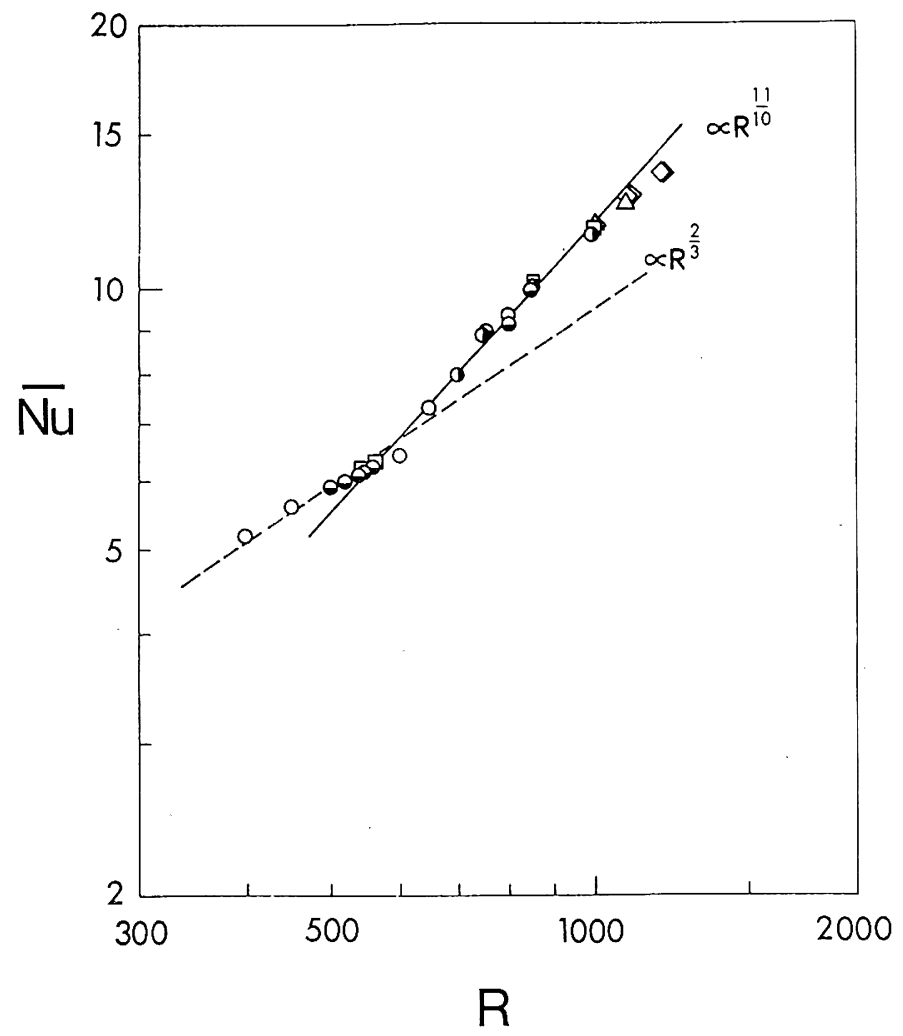

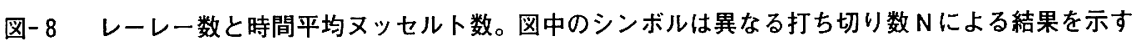
$: \bigcirc, \mathrm{N}=18 ; \bigcirc, 20 ; \ominus, 26 ; \square, 30 ; \triangle, 36 ; \diamond, 42$ (Kimura et al. (1986) に依る)。

Fig. 8 Time-averaged Nusselt number as a function of R. Symbols indicate different truncation numbers : $\bigcirc, \mathrm{N}=18 ; \boldsymbol{\top}, 20 ; \ominus, 26 ; \square, 30 ; \triangle, 36 ; \diamond, 42$ (After Kimura et al., 1986).

図13に $\mathrm{R}=740$ における各水平断面上での $\mathrm{w}$ の分 布を示す。図中の $\mathrm{a}$ 及び $\mathrm{f}$ は上下面に沿って発達し た温度境界層内で带状の構造を持つプルームが存在 し、これらが時間と共に対角線状の上昇及び下降流 れに合流していく。2 次元 $(1,0,1)$ モードの場 合と同様に、振動流れの原因は温度境界層の不安定 に起因していることが分かる。

図14には時間平均した平均ヌッセルト数をRの 関数として示す。 $\mathrm{R}=600$ 前後で $\overline{\mathrm{Nu}}$ の増加率が著し く高くなっている。この領域での $\overline{\mathrm{Nu}}$ は $(1,0,1)$ モードにくらべて大きい值を持つ。またこの時も 2 次元 $(1,0,1)$ モードと同様に $\overline{\mathrm{Nu}} \propto \mathrm{R}$ に近い関係 がみられ、上下面に沿う温度境界層の存在が影著に なっている様子がうかがわれる。

\section{6. あとがき}

飽和多孔質体が下方加熱を受ける場合の 2 次元及 び 3 次元自然対流について述べた。一般に高レー レー数領域に扔いてはいくつかの対流パターンの存 在が可能であるが、本論文においては 2 次元 $(1,0$, 1) モードと 3 次元 $(1,1,1)$ モードに限定して、 流動と温度場の様子及び熱伝導特性を紹介した。い ずれの対流モードにおいてもレーレーが十分大きな 值をもつと定常流加振動流れに遷移していく。初 期の振動流れは規則的単振動により特徵づけられる が、レーレ一数の増加と共に、周波数の増加やより 複雑な振動流れへの進化が見られる。これらの振動 流れは上下面に沿って形成される温度境界層の不安 定に起因している。時間平均された無次元熱伝導率 


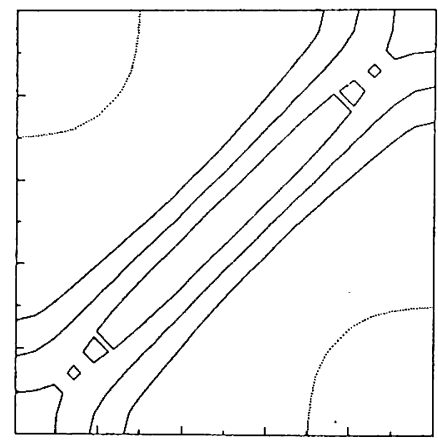

a

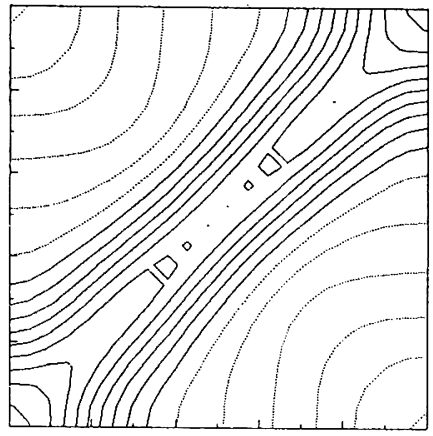

b

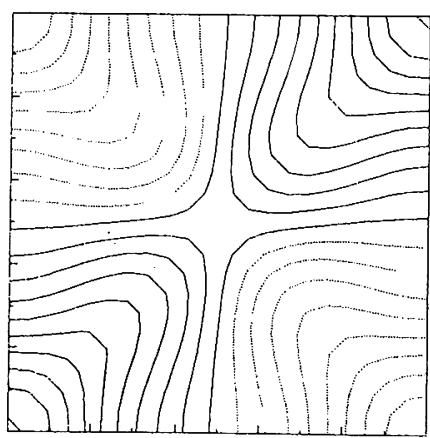

C

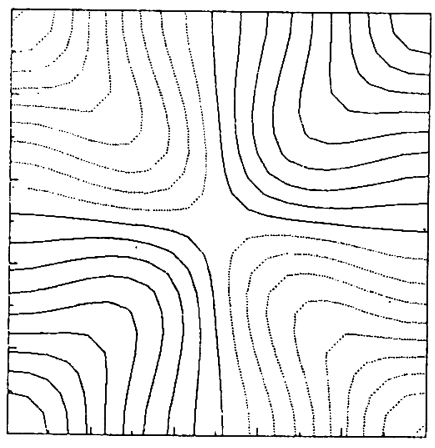

d

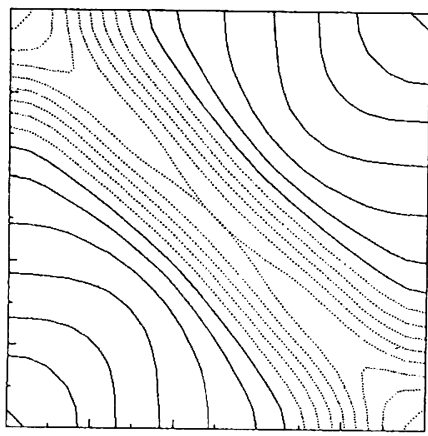

e

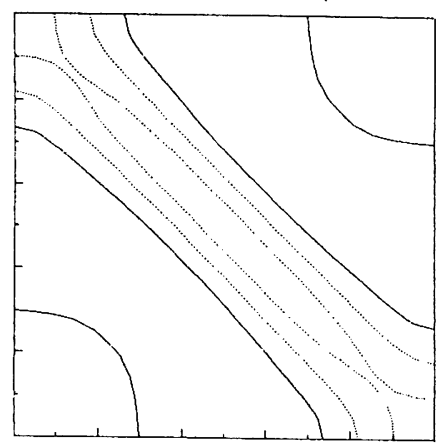

$f$

図-9 $\mathrm{R}=250$ における各水平断面上での $\mathrm{w}$ の分布 $((1,1,1)$ モード)。

実線は正，破線は負の值を示す。各コンターの間隔は $\Delta \mathrm{w}=8$ 。なお，各水平断面の位置は $\mathrm{a}$, $z=0.04$ b, 0.24 c, 0.48 d, 0.52 e, 0.76 f, 0.96 (Kimura et al. (1989) に依る)。

Fig. 9 Contour of $w$ at each horizontal cut at $R=250((1,1,1)$ mode $)$. The contour interval is 8 . Upward flows are shown solid and downward ones are dotted. The positions of horizontal cuts are a, $z=0.04$ b, 0.24 c, 0.48 d, 0.52 e, 0.76 f, 0.96 (After Kimura et al., 1989). 


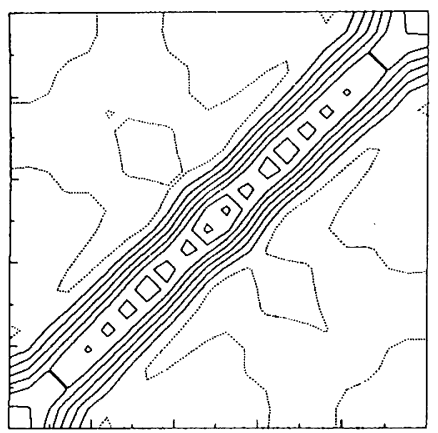

a

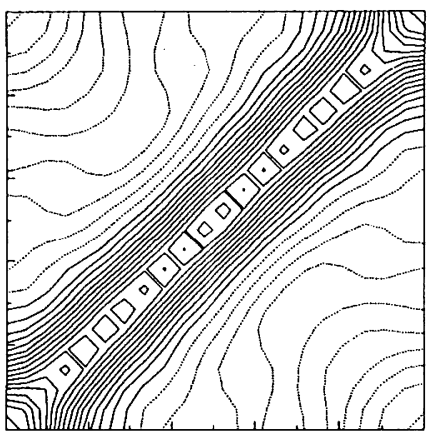

b

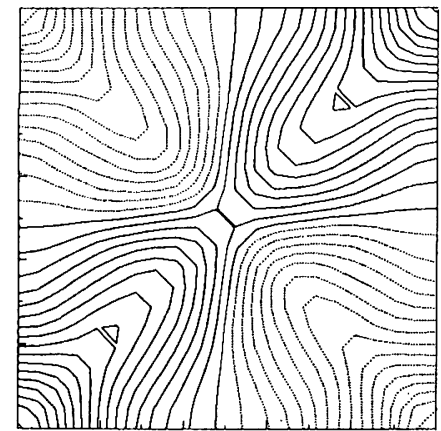

C

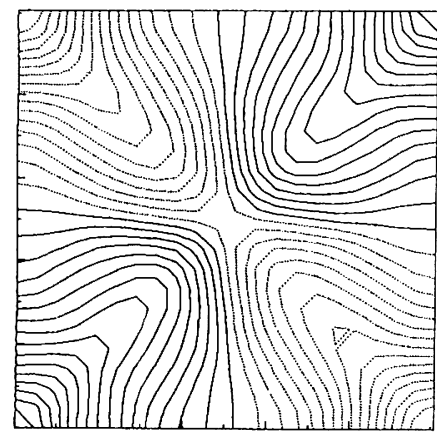

d

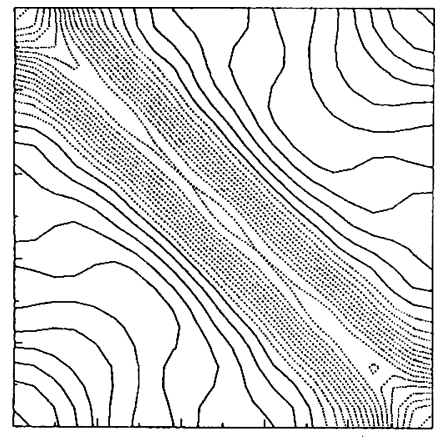

e

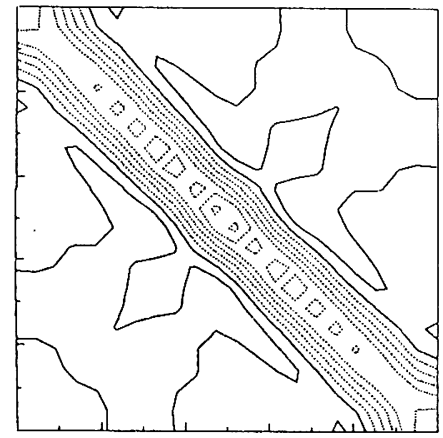

f

図-10 $R=450$ における各水平断面上での $w$ の分布 $((1,1,1)$ モード)。

実線は正，破線は負の値を示す。各コンターの間隔は $\Delta w=8$ 。各水平断面位置は図 9 に同じ。

Fig.10 Contours of $w$ at each horizontal cut at $R=450((1,1,1)$ mode). The contour interval and the positions of a-f are the same as Fig. 9 (Kimura et al., 1989). 


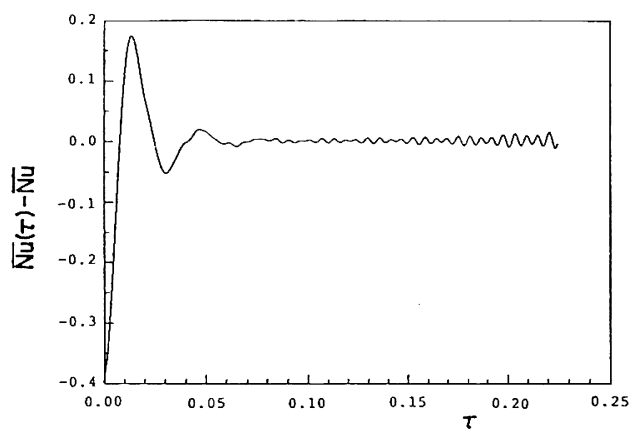

図-11 R=575における単振動対流の発生。

Fig.11 Onset of simply periodic oscillatory convection at $\mathrm{R}=575$ (Kimura et al., 1989).
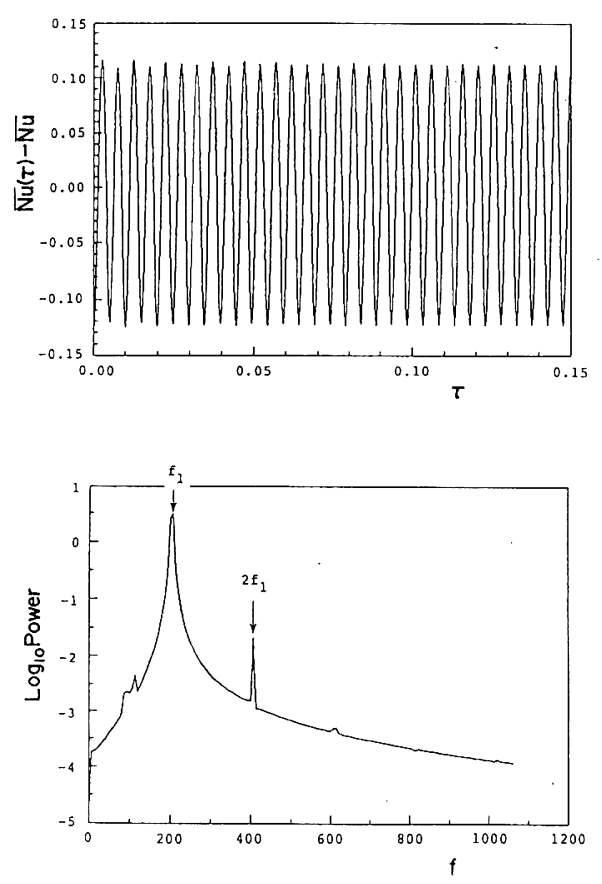

図-12 $R=625$ でのヌッセルト数の時間変化とそのスペ クトルパワー。

下図横軸の $\mathrm{f}$ は無次元振動数を示す。

Fig.12 The Nusselt number time-series and its power spectrum at $R=625$. The horizontal axis in the lower figure shows the oscillation frequency (Kimura et al., 1989).

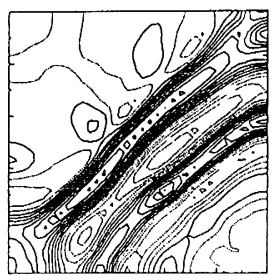

a

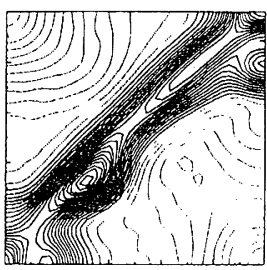

b

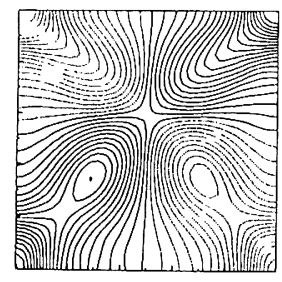

c

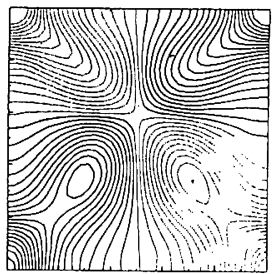

d
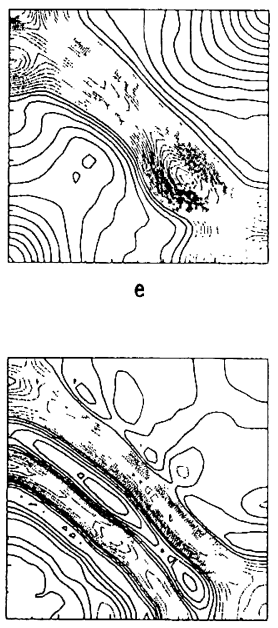

$f$
図-13 $\mathrm{R}=740$ における各水平断面上での $\mathrm{w}$ の分布（(1, 1, 1) モード)。

実線は正，破線は負の値を示す。各コンターの間 隔は $\Delta \mathrm{w}=10$ 。水平断面の位置は $\mathrm{a}, \mathrm{z}=0.03 \mathrm{~b}$, $0.23 \quad c, 0.49$ d, 0.51 e, 0.77 f, 0.97 (Kimura et al. (1989) に依る)。

Fig.13 Contours of $\mathrm{w}$ at each horizontal cut at $\mathrm{R}=740$ $((1,1,1)$ mode $)$. The contour interval is 10 . Upward flows are shown solid and downward ones are dotted. The positions of horizontal cuts are $a, z=0.03 b, 0.23 \quad c, 0.49 \mathrm{~d}$, 0.51 e, 0.77 f, 0.97 (After Kimura et al., 1989). 


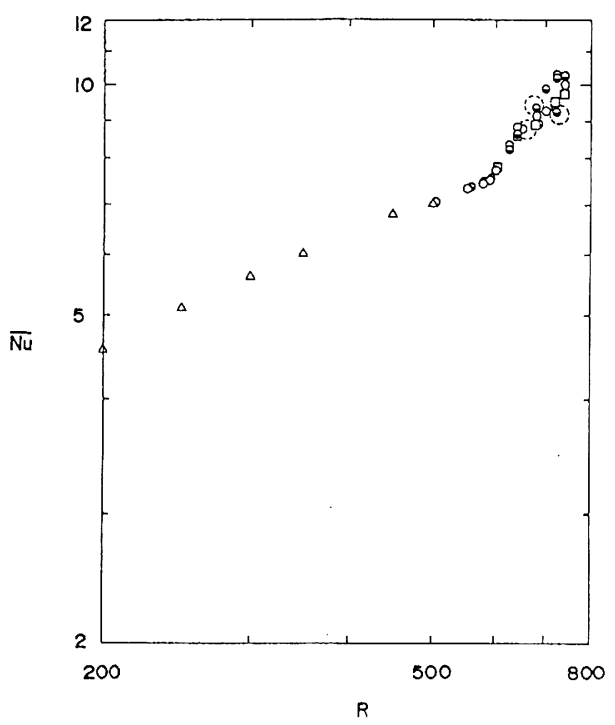

図-14 時間平均ヌッセルト数とレーレー数。各種シンボ ルは打ち切り数 $\mathrm{N}$ の違いを示す $(\triangle, \mathrm{N}=20 \quad \mathrm{O}$, $26 \ominus, 30 \square, 34)$. 図中の破線円は振動流れの振動モードの違いを示 す (Kimura et al. (1989) に依る)。

Fig.14 Time-averaged Nusselt number as a function of Rayleigh number. Different symbols indicate different truncation numbers, $\triangle, N=20 \bigcirc$, $26 \ominus, 30 \square, 34$. Dotted circles indicate the peaks observed in a differnt oscillatory regime at the same Rayleigh number (After Kimura et al., 1986).

であるヌッセルト数 $\overline{\mathrm{Nu}}$ はレーレー数が500以上の 領域では、何れのモードに扔いてもほぼ $\overline{\mathrm{Nu}} \propto \mathrm{R} の$ 関係を有する。

\section{参 考 文 献}

Aidun, C. K and Steen, P. H. (1987) : Transition to oscillatory heat transfer in a fluid-saturated porous medium. J. Thermophys. 1, 268-273.

Caltagirone, J. P. (1975) : Thermoconvective instabilities in horizontal porous layer. J. Fluid Mech. 72, 269-287.

Cheng, P. (1978) : Heat transfer in gothermal systems. Advances in Heat Trans. 14, 1-105.

Elder, J. W. (1967) : Steady free convection in a porous medium heated from below, J. Fluid Mech. 27, 29-50.

Gottlieb, D. and Orszag, S. A. (1977) Numerical Analysis of Spectral Methods : Theory and Applications. Soc. for Ind. and Appl. Math., Philadelphia.

Horne, R. N. and O'Sullivan, M. J. (1974) : Oscillatory convection in a porous medium. J. Fluid Mech. 66, 339-352.

Kimura, S., Schubert, G. and Straus, J. M. (1986) : Route to chaos in porous-medium thermal convection. J. Fluid Mech. 166, 305-324.

Kimura, S., Schubert, G. and Straus, J. M. (1987) : Instabilities of steady, periodic and quasi-periodic modes of convection in porous media. J. Heat Transfer 109, 350-355.

Kimura, S., Schubert, G. and Straus, J. M. (1989) : Timedependent convection in a fluid-saturated porous cube heated from below. J. Fluid Mech. 207, 153-189.

Kimura, S. (1989) : Post-critical behaviors of twodimensional roll cells in an three-dimensional space of fluid-saturated porous layer heated from below ; numerical analysis by pseudo-spectral method. Numerical methods in Thermal Problems Vol. V, 462-468, edited by R. W. Lewis \& K. Morgan, Pineridge Press, Swansea (UK).

Lapwood, E. R. (1948) : Convection of a fluid in a porous medium. Proc. Camb. Phil. Soc. 44, 508-521.

Riley, D. S. and Winters, K. H. (1990) : A numerical bifurcation study of natural convection in a tilted twodimensional porous cavity. J. Fluid Mech. 215, 309-329.

Straus, J. M. and Schubert, G. (1979) : Three-dimensional convection in a cubic box of fluid-saturted porous material. J. Fluid Mech. 91, 155-165.

(受付：1991年 5 月18日、受理：1991年11月18日) 